\title{
Pengajaran Semantik pada Mahasiswa IKIP PGRI Pontianak
}

\author{
Mai Yuliastri Simarmata
}

Program Studi Pendidikan Bahasa dan Satra Indonesia, IKIP PGRI Pontianak, Indonesia

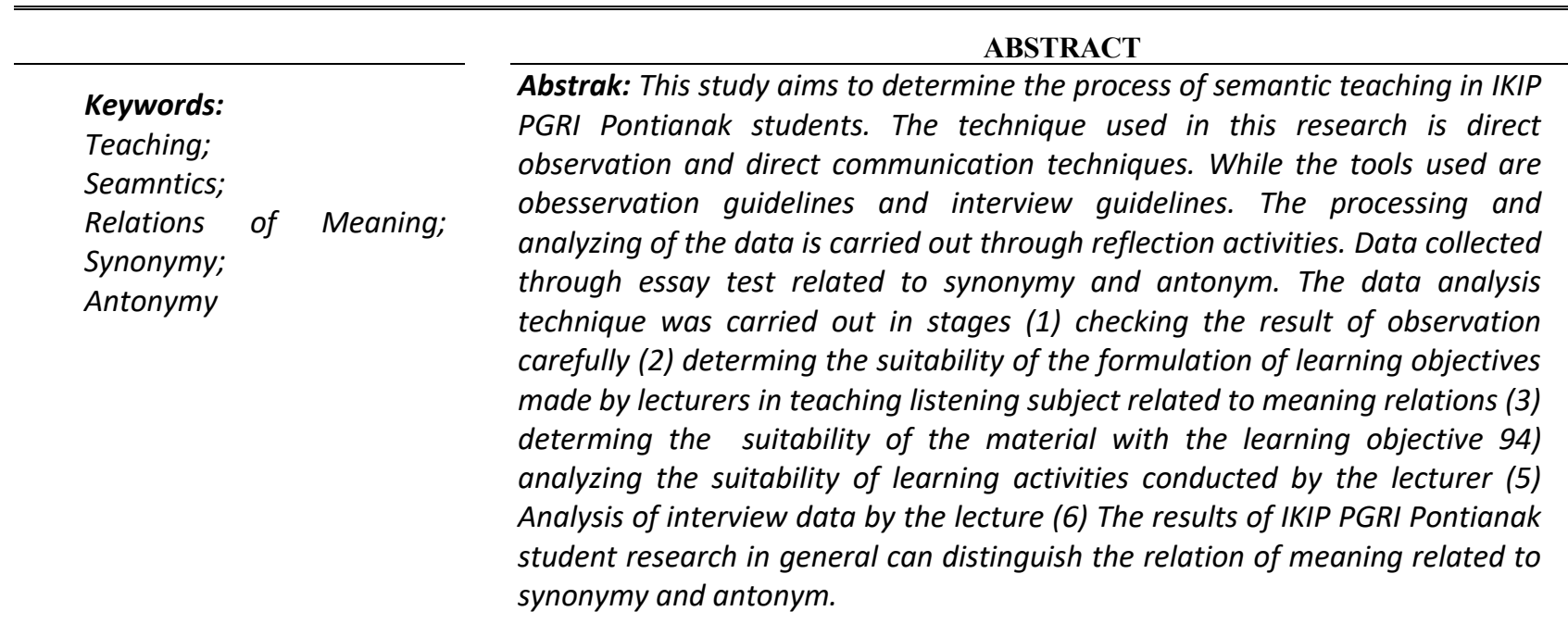

Kata Kunci:

Pengajaran;

Semantik;

Relasi Makna;

Sinonimi;

Antonimi

\begin{abstract}
Abstrak: Penelitian ini bertujuan untuk mengetahui proses pengajaran semantik pada mahasiswa IKIP PGRI Pontianak. Teknik yang digunakan dalam penelitian ini adalah adalah teknik observasi langsung dan teknik komunikasi langsung. Alat yang digunakan adalah pedoman observasi dan pedoman wawancara. Teknik mengolah dan menganalisis data dilakukan melalui kegaitan refleksi. Data yang dikumpulkan melalui tes essay terkait sinonimi dan antonimi. Teknik analisis data dilakukan dengan tahap, yaitu: (1) Memeriksa hasil observasi secara seksama; (2) menentukan kesesuaian rumusan tujuan pembelajaran yang dibuat oleh dosen dalam mengajarkan mata kuliah menyimak terkait relasi makna; (3) menentukan kesesuaian materi dengan tujuan pembelajaran; (4) menganalisis kesesuaian kegiatan pembelajaran yang dilaksanakan oleh dosen; (5) Analisis terhadap data hasil wawancara dengan cara menyesuaikan antara pertanyaan dengan jawaban yang diberikan oleh dosen; (6) menarik simpulan. Hasil penelitian mahasiswa IKIP PGRI Pontianak secara umum dapat membedakan relasi makna terkait sinonimi dan antonimi
\end{abstract}

Correspondance address:

E-mail: maiyuliastrisimarmata85@gmail.com (Mai Yuliastri Simarmata)

\section{Pendahuluan}

Pemerintah selalu berupaya untuk meningkatkan kualitas pendidikan. Pendidikan adalah kunci terbangunnya peradapan. Peradaban dan keberlangsungan hidup manusia terjadi karena adanya pembaharuan diri (self renewel) yang berkelanjutan. Oleh karena itu, dosen sebagai tenaga pendidik harus selalu berupaya untuk kreatif di dalam proses pembelajaran.

Semantik merupakan mata kuliah wajib pada program Studi Pendidikan Bahasa dan Sastra Indonesia. Kompetensi mata kuliah semantik adalah memberikan kompetensi kepada mahasiswa 
sehingga mereka memiliki pengetahuan dan wawasan yang memadai tentang seluk-beluk dan makna, ketaksaan, analisis kompensional, perubahan makna, dan majas serta ungkapan. Berdasarkan pendapat Tarigan (2015), semantik adalah telaah makna. Semantik menelaah lambang-lambang atau tanda-tanda yang menyatakan makna, hubungan maknya yang satu dengan yang lain, dan pengaruhnya terhadap manusia. Sejalan dengan pendapat Tarigan, Pateda (2018) menyimpulkan bahwa semantik adalah subdidisiplin linguistik yang membicarakan makna. Dengan kata lain, semantik berobjekkan makna.

Berbeda dengan pendapat di atas, Simarmata (2016) mengungkapkan semantik adalah bidang linguistik yang mempelajari hubungan antara tanda linguistik itu dengan hal-hal yang ditandainya. Dengan kata lain, bidang studi dalam semantik mempelajari makna-makna yang terdapat dalam satuan bahasa. Semantik terkait dengan makna. Makna yang dibahas dalam penelitian ini adalah makna sinonim dan makna antonim.

Kata semantik sebenarnya merupakan istilah teknis yang mengacu pada studi tentang makna. Istilah ini merupakan istilah baru dalam bahasa Inggris. Para ahli bahasa memberikan pengertian semantik sebagai cabang ilmu bahasa yang mempelajari hubungan antara tanda-tanda linguistik atau tanda-tanda lingual dengan hal-hal yang ditandainya (makna). Istilah lain yang pernah digunakan hal yang sama adalah semiotika, semiologi, semasiologi, dan semetik. Pembicaraan tentang makna kata pun menjadi objek semantik.

Berdasarkan hasil observasi di kelas AP semester V, diketahui bahwa (1) proses pembelajaran semantik materi relasi makna sangat rendah, (2) mahasiswa belum bisa membuat contoh terkait sinonimi, dan (3) mahasiswa belum dapat membuat contoh terkait antonimi. Masalah terkait pengajaran semantik juga pernah diteliti oleh Kusmara (2014) yang mengembangakan model materi ajar semantik di Universitas Jambi dan Djojosuroto (2014) yang meneliti pengaruh pendekatan pembelajaran dalam penguasaan semantik mahasiswa di Universitas Negeri Manado. Kedua penelitian tersebut memiliki kajian yang berbeda dengan masalah yang peneliti temui di IKIP PGRI Pontianak. Karena itu, peneliti tertarik mengkaji bagaimanakah pembelajaran semantik pada mahasiswa IKIP PGRI Pontianak.

\section{Metode}

Sejalan dengan permasalahan yang diangkat, metode yang digunakan dalam penelitian ini adalah metode deskriptif. Bentuk penelitian yang digunakan dalam penelitian ini adalah bentuk kualitatif. Teknik yang digunakan dalam penelitian ini adalah adalah teknik observasi langsung dan teknik komunikasi langsung. Alat yang digunakan adalah pedoman observasi dan pedoman wawancara. Teknik mengolah dan menganalisis data dilakukan melalui kegaitan refleksi. Data yang dikumpulkan melalui tes essay terkait sinonimi dan antonimi. Teknik analisis data dilakukan dengan tahap, yaitu: (1) memeriksa hasil observasi secara seksama; (2) menentukan kesesuaian rumusan tujuan pembelajaran yang dibuat oleh dosen dalam mengajarkan mata kuliah menyimak terkait relasi makna; (3) menentukan kesesuaian materi dengan tujuan pembelajaran; (4) menganalisis kesesuaian kegiatan pembelajaran yang dilaksanakan oleh dosen; (5) analisis terhadap data hasil wawancara dengan cara menyesuaikan antara pertanyaan dengan jawaban yang diberikan oleh dosen; dan (6) menarik simpulan. Penelitian ini dimulai dari bulan September- Oktober 2019. Adapun yang dijadikan subjek penelitian adalah mahasiswa kelas AP semester 5 berjumlah 35 mahasiswa terdiri dari 5 laki-laki dan 30 perempuan.

\section{Hasil dan Pembahasan}

\section{Pengajaran Semantik}

Pengajaran mata kuliah semantik pada program Studi Pendidikan Bahasa dan Sastra Indonesia IKIP PGRI Pontianak adalah mata kuliah wajib dengan bobot sks 2 . Tujuan pengajaran mata kuliah ini secara umum untuk memberikan kompetensi kepada mahasiswa sehingga mereka memiliki 
pengetahuan dan wawasan yang memadai tentang seluk-beluk dan makna, ketaksaan, analisis kompensional, perubahan makna, dan majas serta ungkapan.

Semantik termasuk ilmu bahasa. Ilmu bahasa terdiri atas empat tataran, yaitu fonologi, morfologi, sintaksis, dan semantik. Dari keempat cabang ilmu tersebut, dapat dibagi menjadi dua bagian besar, yaitu: tata bahasa (gramatika) atau struktur bahasa dan di luar gramatika atau di luar struktur bahasa. Pengajaran semantik adalah salah satu mata kuliah yang harus mahasiswa pelajari. Pengajaran semantik yang harus dipelajari adalah dalam penelitian ini adalah relasi makna terkait sinonimi dan antonimi.

Tujuan pengajaran semantik berdasarkan pendapat Suwandi (2015), yaitu mempelajari semantik maka mahasiswa dapat membedakan makna. Selain itu, bagi Artawan tujuan semantik untuk mengetahui makna kata yang akan mendukung berita.

\section{Relasi Makna}

Pembelajaran semantik terkait dengan materi relasi makna. Suwandi (2015) menyebutkan relasi makna dibagi menjadi sinonimi, antonimi, homonimi, polisemi, hiponimi, ambiguitas, dan redudansi. Berikut ini akan dibicarakan terkait relasi makna sinonimi dan antonimi.

\section{Sinonimi}

Kata sinonimi terdiri dari sin ("sama"atau "serupa") dan akar kata onim "nama" yang bermakna "sebuah kata yang dikelompokkan denag kata-kata laindi dalam klasifikasi yang sama berdasarkan makna umum (Tarigan, 2015). Senada dengan pendapat Tarigan, Rohmadi dkk, (2008) mengungkapkan bahwa sinonimi adalah hubungan atau relasi persamaan makna. Dalam bahasa Indonesia, kata ayah bersinonimi dengan bapak, papap, papi, dan babe. Kata melihat bersinonimi dengan kata memandang, menonton, memeriksa, mengintip, mengintai, menengok, membesuk. Kata membawa bersinonimi dengan kata menggendong, memanggul, memapah, menating, menjinjing, menjunjung, memikul.

Hubungan makna antara dua buah kata yang bersinonim bersifat dua arah. Jadi, kalau kata cantik bersinonim dengan kata ayu, maka kata ayu juga bersinonim dengan kata cantik. Begitu juga kalau kata buruk bersinonim dengan kata jelek. Maka kata jelek bersinonim dengan kata buruk. Kalau dibagankan sebagai berikut.

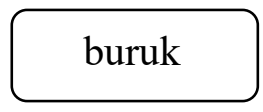

$$
\text { jelek }
$$

Pada definisi di atas dikatakan "maknanya kurang lebih sama". Ini berarti, dua buah kata yang bersinonim itu; kesamaannya tidak seratus persen, hanya kurang lebih saja. Coba perhatikan masalah berikut! Secara matematis kalau kata ban sama maknanya dengan kata roda; dan kata ban juga sama maknanya dengan kata ikat pinggang; maka berarti kata roda sama maknanya dengan kata ikat pinggang; Tetapi ternyata kata roda sedikit pun tidak ada persamaan dengan kata ikat pinggang.

Perhatikan!

$$
\begin{aligned}
& \text { Ban }=\text { roda } \\
& \text { Ban }=\text { ikat pinggang } \\
& \text { Jadi, } * \text { roda = ikat pinggang }
\end{aligned}
$$

Tetapi ternyata roda tidak sama dengan ikat pinggang. Padahal dalam matematika.

$$
\begin{aligned}
& a=b \\
& a=c
\end{aligned}
$$

Maka sudah pasti $b=c$. Ternyata dalam semantik kaidah itu tidak berlaku, kalau ditanya mengapa? karena kesamaan makna antara ban dan roda tidak mutlak $100 \%$ dan kesamaan antara ban dan ikat pinggang juga tidak mutlak $100 \%$. Oleh karena itu, bisa saja terjadi antara roda dan ikat pinggang tidak ada kesamaan sedikit pun. Dengan kata lain, kesamaan makna memang menyentuh ban dan roda, dan ban dan ikat pinggang; tetapi ban dan roda tidak ada sentuhan sedikit pun. Perhatikan bagan berikut ini! 


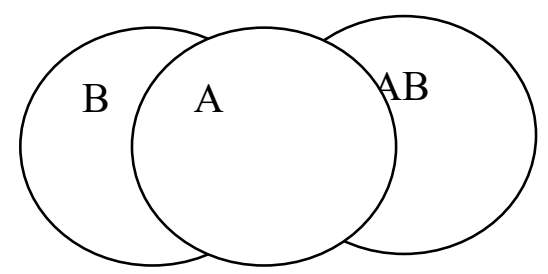
$A=$ ban
$\mathrm{B}=$ roda antara ban dan roda
$C=$ ikat pinggang
$A B=$ bagian makna yang sama
$A C=$ bagian makna yang sama antara ban dan ikat pinggang.

Jadi, kalau ban (A) bersinonim dengan roda (B), memang bisa diterima karena bagian atau unsur maknanya yang sama, yaitu pada bagian $A B$; juga kalau ban $(A)$ bersinonim dengan ikat pinggang (C) juga bisa diterima karena ada bagian atau unsurnya yang sama, yaitu pada bagian AC. Tetapi ban (A) jelas tidak bersinonim dengan ikat pinggang (C) karena antara keduanya tidak ada bagian atau unsur makna yang sama.

Kesinoniman mutlak atau kesinoniman simetris memang tidak ada dalam perbendaharaan kata bahasa Indonesia. Oleh karena itu, kata-kata yang dapat dipertukarkan begitu saja pun jarang ada. Pada suatu tempat kita mungkin dapat menukar kata mati dan kata meninggal; tetapi di tempat lain tidak dapat. Begitu pula kata bunga dan kembang; di satu tempat kita dapat mempertukarkannya, tetapi di tempat lain tidak. Ketidakmungkinan kita untuk menukar sebuah kata dengan kata lain yang bersinonim adalah banyak sebabnya. Antara lain, karena faktor berikut ini.

1. Faktor nuansa makna. Misalnya kata-kata melihat, melirik, melotot, meninjau, dan mengintip adalah kata-kata yang bersinonim. Kata melihat memang bisa digunakan secara umum; tetapi kata melirik hanya digunakan untuk menyatakan melihat dengan sudut mata; kata melotot hanya digunakan untuk melihat dengan mata terbuka lebar; kata meninjau hanya digunakan untuk melihat dari tempat jauh atau tempat tinggi; dan kata mengintip hanya cocok digunakan untuk melihat dari celah yang sempit. Contoh lain, kata hotel bersinonim dengan kata penginapan; tetapi kata penginapan lebih luas maknanya dari kata hotel sebab ke dalam penginapan termasuk juga hotel, losmen, dan motel. Contoh lain yang sedang populer, kata mantan bersinonim dengan kata bekas. Tetapi kata bekas bersifat umum, dapat digunakan untuk apa saja, seperti bekas guru, bekas pacar, bekas lurah, dan bekas benteng. Sedangkan kata mantan hanya berkaitan dengan jabatan terhormat yang pernah di duduki seperti mantan gubernur, mantan lurah, mantan pacar, atau mantan suami, maka akan diterima sebagai gurauan.

2. Faktor waktu. Misalnya kata hulubalang bersinonim dengan kata komandan. Namun, keduanya tidak mudah dipertukarkan karena kata hulubalang hanya cocok untuk situasi kuno, klasik, atau arkais. Sedangkan kata komandan hanya cocok untuk situasi masa kini (modern).

3. Faktor sosial. Misalnya kata aku dan saya adalah dua buah kata yang bersinonim; tetapi kata aku hanya dapat digunakan untuk teman sebaya dan tidak dapat digunakan kepada orang yang lebih tua atau yang status sosialnya lebih tinggi.

4. Faktor tempat atau daerah. Misalnya kata saya dan beta adalah bersinonim. Tetapi kata beta hanya cocok untuk digunakan dalam konteks pemakaian bahasa Indonesia timur (Maluku); sedangkan kata saya dapat digunakan secara umum dimana saja.

5. Faktor bidang kegiatan. Misalnya kata tasawuf, kebatinan, dan mistik adalah tiga buah kata yang bersinonim. Namun, kata tasawuf hanya lazim dalam agama Islam; kata kebatinan untuk yang bukan Islam; dan kata mistik untuk semua agama. Comtoh lain kata matahari bersinonim dengan kata surya; tetapi kata surya hanya cocok atau hanya lazim digunakan dalam sastra, sedangkan kata matahari dapat digunakan secara umum. 


\section{Antonimi}

Kata antonimi berasal dari kata Yunani Kuno, yaitu onoma yang artinya 'nama', dan anti yang artinya 'melawan'. 'Maka' secara harfiah antonimi berarti 'nama lain untuk benda lain pula'. Secara semantik, Verhaar (1978: 24) mendefinisikan sebagai: ungkapan (biasanya berupa kata, tetapi dapat pula dalam bentuk frase atau kalimat) yang maknanya dianggap kebalikan dari makna ungkapan lain. Misalnya dengan kata bagus adalah berantonimi dengan kata buruk; kata besar adalah berantonimi dengan kata kecil; dan kata membeli berantonimi dengan kata menjual.

Hubungan makna antara dua buah kata yang berantonim bersifat dua arah. Jadi, kalau kata bagus berantonim dengan kata buruk maka kata buruk juga berantonim dengan kata bagus; dan kalau kata membeli berantonim dengan kata menjual maka kata menjual pun berantonimi dengan kata membeli. Kalau dibagankan adalah sebagai berikut.

\section{Cantik}

\section{Buruk}

Sama halnya dengan sinonim, antonim pun terdapat pada semua tataran bahasa: tataran morfem, tataran kata, tataran frase, dan tataran kalimat. Hanya barangkali mencari contohnya dalam setiap bahasa tidak mudah. Dalam bahasa Indonesia, untuk tataran morfem (terikat) barangkali tidak ada; dalam bahasa Inggris kita jumpai contoh thankful dengan thankless, dimana full dan less berantonim; antara progresif dengan regresif di mana pro dan re berantonim; juga antara bilingual dengan monolingual, bi dan mono berantonim.

Dalam buku-buku pelajaran bahasa Indonesia, antonim biasanya disebut lawan kata. Banyak orang yang tidak setuju dengan istilah ini sebab pada hakikatnya yang berlawanan bukan kata-kata itu, melainkan makna dari kata-kata itu. Maka, mereka yang tidak setuju dengan istilah lawan kata lalu menggunakan istilah lawan makna. Namun, benarkan dua buah kata yang berantonim, maknanya benar-benar berlawanan? Benarkah hidup lawan mati? Putih lawan hitam? Dan menjual lawan membeli? Sesuatu yang hidup memang belum atau tidak mati, dan sesuatu yang mati memang sudah tidak hidup. Jadi, memang berlawanan. Apakah juga yang putih berarti tidak hitam? Belum tentu, mungkin kelabu. Menurut ilmu fisika putih adalah warna campuran dari segala warna, juga sesuatu yang jauh berarti tidak dekat? Juga belum tentu. Tampaknya soal jauh atau dekat bersifat relatif. Patokannya tidak tentu bisa digeser. Soal menjual dan membeli tampaknya merupakan dua hal yang berlaku bersaman; tidak ada proses pembelian tanpa terjadinya proses penjualan. Begitu juga sebaliknya.

Berdasarkan uraian di atas, dapat dilihat bahwa antonim pun sama halnya dengan sinonim, tidak bersifat mutlak. Itulah sebabnya barangkali dalam batasan di atas, Verhaar menyatakan yang maknanya dianggap kebalikan dari makna ungkapan lain". Jadi, hanya dianggap kebalikan. Bukan mutlak berlawanan.

\section{Keberhasilan Mahasiswa dalam pembelajaran semantik}

Proses pengjaran mata kuliah semantik di kelas AP semster V dikatakan berhasil karena sesuai dengan RPS yang telah dibuat oleh dosen. Untuk mengetahui tercapai atau tidaknya tujuan pembelajaran dosen mengadakan tess essay dengan tujuan untuk mengetahui sejauh mana mahasiswa mengetahui terkait pembelajaran semantik. Hasil tes dapat menunjukkan hasil belajar dengan beberapa tingkatan/taraf sebagai berikut istimewa/maksimal, baik sekali/optimal, dan kurang. Dikatakan istimewa apabila seluruh tes dapat dikerjakan dengan baik dan dikatakan optimal/baik sekali apabila sebagian besar (76\%-99\%) tes dapat dikerjakan oleh mahasiswa. Dikatakan kurang apabila tes dapat dikuasai kurang dari 60\%. Berdasarkan hasil penelitian dari 35 mahasiswa 95 persen mahasiswa dapat membedakan relasi makna terkait sinonimi dan antonimi. Oleh karena itu, dapat disimpulkan bahwa pembelajaran mata kuliah semantik berhasil. 


\section{Simpulan}

Berdasarkan hasil penelitian di atas, dapat disimpulkan bahwa 1) tujuan pembelajaran pada mata kuliah semantik sudah baik. Hal ini dilihat dari hasil tes yang diberika; 2) mahasiswa dapat membedakan relasi makna terkait dengan sinonimi dan antonimi; 3) kegiatan pembelajaran yang sudah dilakukan oleh peneliti berjalan dengan baik; dan 4) selama pembelajaran berlangsung peneliti tidak mengalami hambatan.

\section{Daftar Pustaka}

Djojosuroto, K. 2014. Pengaruh Pendekatan Pembelajaran dan Penguasaan Semantik terhadap Peningkatan Pemahaman Makna Puisi. LiNGUA: Jurnal IImu Bahasa dan Sastra, 9(1), 9-19.

Kusmana, A. 2014. Pengembangan Model Materi Ajar Semantik: Penelitian dan Pengembangan Model Materi Ajar Semantik di Program Studi Bahasa, Sastra Indonesia, dan Daerah FKIP Universitas Jambi. Lentera Pendidikan: Jurnal IImu Tarbiyah dan Keguruan, 17(1), 1-17.

Pateda, Mansoer. 2010. Semantik Leksikal. Pt Rineka Cipta.

Rohmadi. Dkk,. 2008. Semantik: Teori dan Analisis. Surakrta. Yuma Prssindo

Simarmata, M. Y. 2016. “Analisis Unsur Leksikal dalam Wacana Pada Surat Kabar Tribun Pontianak Rubrik 'Borneo Sport'(Edisi, 16 Mei-21 Mei 2014)”. Jurnal Pendidikan Bahasa, vol.3, no. 2, hlm. 211-224.

Suwandi, Sarwiji. 2011. Semantik: Pengantar Kajian Makna. Surakarta: Yuma Pressindo.

Tarigan, Hendry. 2015. Pengajaran Semantik. Bandung: Cv Angkasa. 